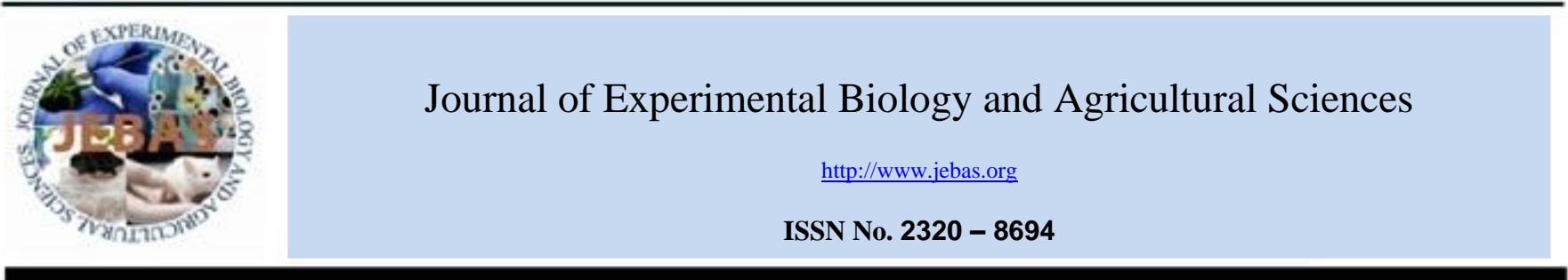

\title{
ANTIVIRAL PROPERTIES OF MICROALGAE AND CYANOBACTERIA
}

\section{Manishaa Sri Mahendran ${ }^{1}$, Sinouvassane Djearamane ${ }^{2}$, Ling Shing Wong ${ }^{3}$, Govindaraju Kasivelu ${ }^{4}$, Anto Cordelia Tanislaus Antony Dhanapa $1^{1^{*}}$}

\author{
${ }^{1}$ Department of Chemical Science, Faculty of Science, Universiti Tunku Abdul Rahman, Kampar, 31900 Malaysia; \\ ${ }^{2}$ Department of Biomedical Science, Faculty of Science, Universiti Tunku Abdul Rahman, Kampar, 31900 Malaysia \\ ${ }^{3}$ Life Science Division, Faculty of Health and Life Sciences, INTI International University, Nilai, 71800 Malaysia; \\ ${ }^{4}$ Centre for Ocean Research, MoES - Earth Science \& Technology Cell (Marine Biotechnological Studies), Sathyabama Institute of Science and Technology (Deemed to \\ be University), Chennai, 600119 India.
}

Received - July 18, 2020; Revision - September 17, 2020; Accepted - January 03, 2021

Available Online - March 25, 2021

DOI: http://dx.doi.org/10.18006/2021.9(Spl-1-GCSGD_2020).S43.S48

\section{KEYWORDS}

Microalgae

Cyanobacteria

Antiviral properties

Bioactive compounds

\section{ABSTRACT}

The recent outbreak of Corona Virus Disease (COVID-19) and the surge in accelerating the development of a vaccine to fight against the SARS-CoV-2 virus has imposed greater challenges to humanity worldwide. There is lack of research into the production of effective vaccines and methods of treatment against viral infections. As of now, strategies encompassing antiviral drugs and corticosteroids alongside mechanical respiratory treatment are in practice as frontline treatments. Though studies have reported that microalgae possess antiviral properties, only a few cases have presented the existence of antiviral compounds such as algal polysaccharides, lectins, aggluttinins, scytovirin, algal lipids such as sulfoquinovosyldiacylglycerol (SQDG), monogalactosyldiacylglycerides (MGDG) and digalactosyldiacylglycerides (DGDG), and algal biopigments especially chlorophyll analogues, marennine, phycobiliproteins, phycocyanin, phycoerythrin and allophycocyanin that are derived from marine and freshwater microalgae. Given the chemodiversity of bioactive compounds from microalgae and the present scenario, algal biotechnology is seen as a prospective source of antiviral and antiinflammatory compounds that can be used to develop antiviral agents. Microalgae with potential as antivirals and microalgae derived functional compounds to treat viral diseases are summarized and can be used as a reference in developing algae-derived antivirals to treat SARS-CoV-2 and other similar viruses.
* Corresponding author

E-mail: antoc@utar.edu.my (Anto Cordelia Tanislaus Antony Dhanapal)

Peer review under responsibility of Journal of Experimental Biology and Agricultural Sciences.

Production and Hosting by Horizon Publisher India [HPI] (http://www.horizonpublisherindia.in/).

All rights reserved.
All the articles published by Journal of Experimental Biology and Agricultural Sciencesare licensed under a Creative Commons Attribution-NonCommercial 4.0 International License Based on a work at www.jebas.org.

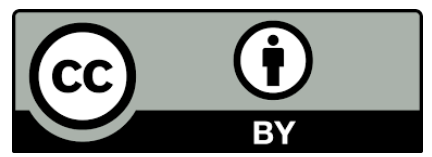




\section{Introduction}

Research activities to classify compounds used to prevent and treat severe and acute viral infections are now a priority and society has been hesitant and unable to seek scientific solutions (Liu et al., 2020). The complex life cycle and the distinctive nature of the viruses have made it highly difficult to discover definite remedies against viral infections (Murrell et al., 2011).

A variety of diseases, such as hepatitis $\mathrm{C}(\mathrm{HCV})$, human immunodeficiency virus (HIV) and dengue virus (DENV) still affects the majority of people of the world's population over decades, despite comprehensive studies of effective vaccines and viral infection treatment over the last century (Graci \& Cameron, 2005).

To date, the development of vaccines against certain viruses such as HIV and $\mathrm{HCV}$ has proven to be an intractable strategy and specific vaccine are not found against many common viral infections, including herpesviruses (Ahmadi et al., 2015) and respiratory tract viruses such as Severe Acute Respiratory Syndrome and Middle East Respiratory Syndrome.

Besides, drug resistance of various viruses (HIV-1 and HSV), to available antiviral agents has often been a significant obstacle for antiviral medications (De Clercq, 2002).

The complex aquatic ecosystem has given the world of the marine environment a range of algae from micro-organisms to giant algae. Microalgae and cyanobacteria have been used for millennia as food in ancient Asian, African, and South American cultures. However, only by the middle of the past century biotechnology for microalgae begin to evolve (Mendes et al., 2003).

Microalgae and cyanobacteria provide immense prospects in industries such as pharmaceuticals, foodstuffs, or cosmetics for isolating natural substances of considerable commercial interest. Further, numerous research studies have evidenced the antiviral property of microalgal compounds (Mayer \& Hamann, 2005) that proposes microalgae as a potent source for a natural antiviral agent. This review article summarizes the antiviral activities of the purified biomolecules from the microalgae.

\section{Algae derived biomolecules as antiviral agents}

\subsection{Polysaccharides}

Research by Gerber et al. (1958) found that an important source of antiviral agents with polysaccharides was the inhibition of influenza B viruses by marine algae polysaccharides. Anti-viral activity of other red algae-insulated polysaccharide fractions against HSV and HIV-1 have been recorded over the past two decades. Since then, several studies have shown that some algaedriven polysaccharides have antiviral potential and underlying action mechanisms as shown in Table 1.

The sulphated exopolysaccharides of marine microalgae such as Porphyridium sp. and Cochlodidium polykrikoides are found to interact with certain enveloped viruses like HSV and HIV, preventing them from reaching the host cells (Amaro et al., 2011) and also exhibited antiviral action against type 1 and 2 HSV in both in vitro and in vivo rabbits and rats (Huleihel et al., 2001). The antiviral property of the polysaccharides from Porphyridium sp. was due to the neighboring attachment of HSV-1 particles to polysaccharides (Batinic \& Robey, 1992). Also, naviculan is an extracellular sulphated polysaccharide produced by Navicula directta diatom. The naviculan contains galactose, rhamnose, xylose, fucose, sulfate, and manna that reported to have an

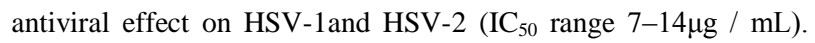
Besides, naviculan hinders influenza viruses at the early stages of virus-related response, possibly preventing the virus from entering the host cells (Lee et al., 2010).

Cyanobacteria contain vital antiviral compounds. Arthrospira platensis is a blue-green alga that consists of exopolysaccharides. This exopolysaccharide has an antiviral activity for Koi Herpes Virus (KHV), which is accountable for significant economic losses in common carp and koi (Reichert et al., 2017). Polysaccharides enriched fraction at 18 to $36 \mu \mathrm{g} / \mathrm{mL}$ inhibits the replication of the virus (Haslin et al., 2001). S. platensis extract is known as calcium spirulan (Ca-SP) which is a form of sulphated polysaccharide. CaSP consists of ribose, mannose, galactose, fructose, and rhamnose which will intrude the replication of both enveloped (HIV, influenza A) and non-enveloped (HSV, polio, cytomegalovirus) viruses (Takebe et al., 2013).

\subsection{Proteins}

Proteins with antiviral activities are also produced by various species of cyanobacteria and microalgae. Glycoproteins or carbohydrate-binding proteins are known as lectins.

Lectins can bind with carbohydrates and carbohydrate moieties of glycoconjugates. Different lectins that exert anti-HIV activity by attaching strongly with carbohydrate moieties on the glycosylated HIV envelope have been identified over the last decade (Huskens \& Schols, 2012).

HIV shows a mannose-rich glycoprotein gp120 on its surface envelope which is essential for the virus to bind to the target cells' cellular receptor CD4 (Tiwari et al., 2009). Besides this, there is a strong antiviral activity produced by Scenedesmus obliquus hydrolysates Sd, Sd1 and Sd2 against Coxsackie virus B (Afify et al., 2018). 
Table 1 Polysaccharides from microalgae and cyanobacteria having antiviral activities

\begin{tabular}{|c|c|c|c|}
\hline Compounds & Microalgae & Viruses & Authors \\
\hline Sulfated polysaccharide & Navicula directa & Influenza-A & Ahmadi et al., 2015 \\
\hline Highly sulfated polysaccharide & Porphyridium cruentum & HSV-2, HSV-1, Vaccina & Huang et al., 2007 \\
\hline Sulfated exopolysaccharide & P. purpureum & Vaccina & Radonic et al., 2010 \\
\hline Sulfated polysaccharide & Porphyridium cruentum & Varicella zoster virus & Huleihel et al., 2001 \\
\hline Exopolysaccharides & Rhodella reticulata & Murine sarcoma and leukemia viruses & $\begin{array}{l}\text { Talyshinsky et al., } \\
2002\end{array}$ \\
\hline $\begin{array}{l}\text { Extracellular sulfated } \\
\text { polysaccharide }\end{array}$ & Cochlodinium polykrikoides & Influenza, parainfluenza-2 & Hasui et al., 1995 \\
\hline Calcium spirulan & Arthrospira platensis & measles,influenza & Radonic et al., 2010 \\
\hline Nostaflan & Nostoc flagelliforme & Influenza A virus & Goss \& Jakob, 2010 \\
\hline Carrageenan & Gigartina skottsbergii & Influenza virus, HSV-1,DENV, HSV-2, , HIV & Dye, 2014 \\
\hline Galactan & Cryptonemia crenulata & HSV-1, HSV-2, HIV-1, HIV-2, DENV & Delattre et al., 2011 \\
\hline Alginate & Macrocystis pyrifera & HIV & Zheng et al., 2020 \\
\hline Fucan & Adenocytis utricularis & HSV-1, HCMV, HSV-2, HIV-1 & Salehi et al., 2020 \\
\hline Laminaran & Ascophyllum nodosum & HIV & Edwards et al., 2019 \\
\hline
\end{tabular}

\subsection{Lipids}

Many algal lipids have exhibited antiviral activity to a lesser degree relative to polysaccharides and proteins. Compounds such as sulfoquinovosyldiacylglycerol (SQDG) and monogalactosyldiacylglycerides (MGDG) are primarily sulfolipids and glycolipids (Buck et al., 2006). The high anti-HIV activity was detected in Lyngby alagerheimii and Phormidium tenue's SQDG (Gustafson et al., 1989). Spirulina's methanol extract with an $\mathrm{IC}_{50}$ value of $25.1 \mu \mathrm{g} / \mathrm{mL}$ has antiviral activity against HIV-1 (Zalah et al., 2002; Yim et al., 2004; Li et al., 2008).

\subsection{Pigments}

Different pigments in microalgae and cyanobacteria have shown various biological activities. For example, chlorophyll analogs in Dunaliella primolecta (Ohta et al., 1998) have demonstrated antiHSV activity. Haslea ostrearia is a marine diatom that produces blue pigment, a water-soluble fraction containing marennine $\left(\mathrm{EC}_{50}\right.$ value of $14 \mu \mathrm{g} / \mathrm{mL}$ ), was able to inhibit HSV-1 replication in vitro cells. Additionally, this element prolonged the development of syncytia caused by HIV-1 on cells of MT2 (Kamat et al., 1992;
Shih et al., 2003). Phycobiliproteins, the natural coloring in food and pharmaceutical products, are the key photosynthetic additive in cyanobacteria and red algae. The two most commonly known phycobiliproteins are Arthrospira phycocyanin and Porphyridium phycoerythrin. They have reported showing antiviral properties that turned them into a promising material for health applications. Table 2 states the commercial application of the algae and cyanobacteria derived antivirus compounds.

\section{Conclusion}

Various biological activities, including the transcendent antiviral effect, have been documented for algal purified molecules. Numerous pharmacological studies have been only conducted in host cells as in vitro studies. Nevertheless, in vivo studies are essential to promote the usage of microalgal products in the pharmaceutical industry as effective anti-viral agents. Additionally, new experiments to explore the antiviral activities against infectious viruses, including clinical trials, are another area for further research. 
Table 2 Commercial application of the algae and cyanobacteria derived antivirus compounds

\begin{tabular}{|l|l|l|l|l|}
\hline \multicolumn{1}{|c|}{ Microalgae } & \multicolumn{1}{|c}{ Commercial Supplement } & \multicolumn{2}{c|}{ Brand } & Flu, influenza, enterovirus, virus \\
Spirulina & Apogen Children Granules & Febico & & Febico, 2021 \\
\hline Gigartina papillata & Red Marine Algae Plus & Pure Planet & Oral herpes, shingles,genital herpes, & Kelly Horrington, \\
flosaquae & Blue-Green Algae & Source Naturals & HIV/AIDS & 2020 \\
\hline Spirulina & Apogen capsules & Febico & Flu, influenza, enterovirus, dengue & Zizzo et al., 2020 influenza \\
& & & virus, and respiratory syncytial virus & Febico, 2021 \\
\hline
\end{tabular}

\section{References}

Afify A, El Baroty G, El Baz F, Abd El Baky H, Murad S (2018) Scenedesmus obliquus: Antioxidant and antiviral activity of proteins hydrolyzed by three enzymes. Journal of Genetic Engineering and Biotechnology 16(2): 399-408.

Ahmadi A, ZorofchianMoghadamtousi S, Abubakar S, Zandi K (2015) Antiviral Potential of Algae Polysaccharides Isolated fromMarine Sources: A Review. BioMed Research International, pp.1- 10. https://doi.org/10.1155/2015/825203.

Batinić D, Robey F (1992) The V3 region of the envelope glycoprotein of human immunodeficiency virus type 1 binds sulfated polysaccharides and CD4-derived synthetic peptides. Journal of Biological Chemistry 267(10): 6664-6671.

Buck C, Thompson C, Roberts J, Müller M, Lowy D, Schiller J (2006) Carrageenan Is a Potent Inhibitor of Papillomavirus Infection. PLoS Pathogens 2(7): 69.

Delattre C, Fenoradosoa T, Michaud P (2011) Galactans: an overview of their most important sourcing and applications as natural polysaccharides. Brazilian Archives of Biology and Technology 54(6): 1075-1092.

De Clercq E (2002) Strategies in the design of antiviral drugs. Nature Reviews Drug Discovery 1(1): 13-25.

Dye C (2014) After 2015: infectious diseases in a new era of health and development. Philosophical Transactions of the Royal Society B: Biological Sciences 369(1645): 20130426.
Edwards T, Mani N, Dorsey B, Kakarla R, Rijnbrand R, Sofia M, Tavis J (2019) Inhibition of HBV replication by $\mathrm{N}$ hydroxyisoquinolinedione and N-hydroxypyridinedione ribonuclease H inhibitors. Antiviral Research 164: 70-80.

Febico (2021) Apogen ${ }^{\circledR}$ Capsules. [online] Far East Bio-Tec Co, Ltd. Available at https://www.febico.com/en/product/MicroalgaeProtein-Capsule.html Accessed 12 November 2020.

Gerber P, Dutcher J, Adams E, Sherman J (1958) Protective Effect of Seaweed Extracts for Chicken Embryos Infected with Influenza B or Mumps Virus. Experimental Biology and Medicine 99(3): 590-593.

Goss R, Jakob T (2010) Regulation and function of xanthophyll cycle-dependent photoprotection in algae. Photosynthesis Research 106(1-2): 103-122.

Graci J, Cameron C (2005) Mechanisms of action of ribavirin against distinct viruses. Reviews in Medical Virology 16(1): 37-48.

Gustafson K, Cardellina J, Fuller R, Weislow O, Kiser R, Snader K, Patterson G, Boyd M (1989) AIDS-Antiviral Sulfolipids From Cyanobacteria (Blue-Green Algae). JNCI Journal of the National Cancer Institute 81(16): 1254-1258.

Haslin C, Lahaye M, Pellegrini M, Chermann J (2001) In Vitro Anti-HIV Activity of Sulfated Cell-Wall Polysaccharides from Gametic, Carposporic and Tetrasporic Stages of the Mediterranean Red Alga Asparagopsis armata. Planta Medica 67(4): 301-305. 
Hasui M, Matsuda M, Okutani K, Shigeta S (1995) In vitro antiviral activities of sulfated polysaccharides from a marine microalga (Cochlodinium polykrikoides) against human immunodeficiency virus and other enveloped viruses. International Journal of Biological Macromolecules 17(5): 293-297.

Huang Z, Guo B, Wong R, Jiang Y (2007) Characterization and antioxidant activity of selenium-containing phycocyanin isolated from Spirulina platensis. Food Chemistry 100(3): 1137-1143.

Huleihel M, Ishanu V, Tal J, Arad S (2001) Antiviral effect of red microalgal polysaccharides on Herpes simplex and Varicella zoster viruses. Journal of Applied Phycology 13(2):127-134.

Huskens D, Schols D (2012) Algal Lectins as Potential HIV Microbicide Candidates. Marine Drugs 10(12): 1476-1497.

Kamat S, Wahidulla S, D'Souza L, Naik C, Ambiye V, Bhakuni D, Goel A, Garg H, Srimal R (1992) Bioactivity of Marine Organisms. VI. Antiviral Evaluation of Marine Algal Extracts from the Indian Coast. Botanica Marina 35(2). DOI: https://doi.org/10.1515/botm.1992.35.2.161.

Kelly Harrington R (2020) What Is Red Marine Algae And What Are Its Health Benefits. [online] Healthy Goods. Available at https://healthygoods.com/blog/red-marine-algae-health-benefits Accessed 8 January 2021].

Lee J, Koizumi S, Hayashi K, Hayashi T (2010) Structure of rhamnansulfate from the green alga Monostroma nitidum and its anti-herpetic effect. Carbohydrate Polymers 81(3): 572-577.

Li B, Lu F, Wei X, Zhao R (2008) Fucoidan: Structure and Bioactivity. Molecules 13(8): 1671-1695.

Liu C, Zhou Q, Li Y, Garner L, Watkins S, Carter L, Smoot J, Gregg A, Daniels A, Jervey S, Albaiu D (2020) Research and Development on Therapeutic Agents and Vaccines for COVID-19 and Related Human Coronavirus Diseases. ACS Central Science 6(3):315-331

Mayer A, Hamann M (2005) Marine pharmacology in 2001-2002: Marine compounds with anthelmintic, antibacterial, anticoagulant, antidiabetic, antifungal, anti-inflammatory, antimalarial, antiplatelet, antiprotozoal, antituberculosis, and antiviral activities affecting the cardiovascular, immune and nervous systems and other miscellaneous mechanisms of action. Comparative Biochemistry and Physiology Part C: Toxicology \& Pharmacology, 140(3-4): 265-286.

Mendes AF, Caramona M, Carvalho A, Lopes M (2003) Hydrogen peroxide mediates interleukin-1 $\beta$-induced $\mathrm{AP}-1$ activation in articular chondrocytes: Implications for the regulation of iNOS expression. Cell Biology and Toxicology 19(4): 203-214.

Murrell S, Wu S, Butler M (2011) Review of dengue virus and the development of a vaccine. Biotechnology Advances 29(2): 239247.

Ohta S, Ono F, Shiomi Y, Nakao T, Aozasa O, Nagate T, Kitamura K, Yamaguchi S, Nishi M, Miyata H (1998) Anti-Herpes Simplex Virus substances produced by the marine green alga, Dunaliella primolecta. Journal of Applied Phycology 10(4): 349-356.

Radonic A, Thulke S, Achenbach J, Kurth A, Vreemann A (2010) Anionic Polysaccharides From Phototrophic Microorganisms Exhibit Antiviral Activities to Vaccinia Virus. Journal of Antivirals \& Antiretrovirals 02(04)

Reichert M, Bergmann SM, Hwang J, Buchholz R, Lindenberger C (2017) Antiviral activity of exopolysaccharides from Arthrospira platensis against koi herpesvirus. The Journal of Fish Diseases 40:1441-1450.

Salehi S, Abedi A, Balakrishnan S, Gholamrezanezhad A (2020) Coronavirus Disease 2019 (COVID-19): A Systematic Review of Imaging Findings in 919 Patients. American Journal of Roentgenology 215(1): 87-93.

Shih S, Tsai K, Li Y, Chueh C, Chan E (2003) Inhibition of enterovirus 71-induced apoptosis by allophycocyanin isolated from a blue-green alga Spirulina platensis. Journal of Medical Virology 70(1): 119-125.

Takebe Y, Saucedo C, Lund G, Uenishi R, Hase S, Tsuchiura T, Kneteman N, Ramessar K, Tyrrell D, Shirakura M, Wakita T, McMahon J, O'Keefe B (2013) Antiviral Lectins from Red and Blue-Green Algae Show Potent In Vitro and In Vivo Activity against Hepatitis C Virus. PLoS ONE 8(5): 64449.

Talyshinsky M, Souprun Y, Huleihel M (2002) Anti-viral activity of red microalgal polysaccharides against retroviruses. Cancer Cell International 2(1): 8.

Tiwari V, Shukla S, Shukla D (2009) A sugar binding protein cyanovirin-N blocks herpes simplex virus type-1 entry and cell fusion. Antiviral Research 84(1): 67-75.

Yim J, Kim S, Ahn S, Lee C, Rhie K, Lee H (2004) Antiviral Effects of Sulfated Exopolysaccharide from the Marine Microalga Gyrodiniumimpudicum Strain KG03. Marine Biotechnology 6(1): $17-25$.

Zalah L, Huleihel M, Manor E, Konson A, Ford H, Marquez V, Johns D, Agbaria R (2002) Metabolic pathways of N- 
methanocarbathymidine, a novel antiviral agent, in native and herpes simplex virus type 1 infected Vero cells. Antiviral Research 55(1): 63-75.

Zheng L, Chen X, Cheong K (2020) Current trends in marine algae polysaccharides: The digestive tract, microbial catabolism and prebiotic potential. International Journal of Biological
Macromolecules 151:344-354.

Zizzo MZ, Caldara G, Bellanca A, Nuzzo D, Carlo MD, Scoglio S, Serio R (2020) AphaMax ${ }^{\circledR}$, an Aphanizomenon Flos-Aquae Aqueous Extract, Exerts Intestinal Protective Effects in Experimental Colitis in Rats. Nutrients 2020, 12(12), 3635; https://doi.org/10.3390/nu12123635. 